Southern Illinois University Carbondale

OpenSIUC

Publications

Fisheries and Illinois Aquaculture Center

3-2009

\title{
Declining Recruitment and Growth of Shovelnose Sturgeon in the Middle Mississippi River: Implications for Conservation
}

Sara J. Tripp

Robert E. Colombo

James E. Garvey

Southern Illinois University Carbondale

Follow this and additional works at: http://opensiuc.lib.siu.edu/fiaq pubs

Copyright by the American Fisheries Society 2009

Published in Transactions of the American Fisheries Society, Vol. 138, Issue 2 (March 2009) at doi:

10.1577/T08-024.1

\section{Recommended Citation}

Tripp, Sara J., Colombo, Robert E. and Garvey, James E. "Declining Recruitment and Growth of Shovelnose Sturgeon in the Middle Mississippi River: Implications for Conservation." (Mar 2009).

This Article is brought to you for free and open access by the Fisheries and Illinois Aquaculture Center at OpenSIUC. It has been accepted for inclusion in Publications by an authorized administrator of OpenSIUC. For more information, please contact opensiuc@lib.siu.edu. 


\title{
Declining Recruitment and Growth of Shovelnose Sturgeon in the Middle Mississippi River: Implications for Conservation
}

\author{
Sara J. Tripp, Robert E. Colombo, and James E. Garvey* \\ Fisheries and Illinois Aquaculture Center, Department of Zoology, \\ Southern Illinois University, Carbondale, Illinois 62901, USA
}

\begin{abstract}
To determine how populations of shovelnose sturgeon Scaphirhynchus platorynchus are changing and may respond to poor environmental conditions, current commercial harvest of black-egg (sexually mature) females, and incidental mortality of males, we require annual information about sexspecific age structure as it relates to the recruitment of new cohorts. We sampled shovelnose sturgeon by use of gill nets (5-cm bar mesh) monthly during 2002-2006 in the Middle Mississippi River between Cairo, Illinois, and St. Louis, Missouri. We compared patterns of size and age structure over time and projected age structure and population size into the future. Sex ratio in 2005-2006 was 1.14:1.00 (416 males and 363 females; $P=0.06$ ), deviating from the $1: 1$ ratio that occurred in 2002-2003. Annual mortality increased from $37 \%$ in $2002-2003$ to $44 \%$ by $2005-2006$. Female shovelnose sturgeon were larger than males. Across years, the population shifted toward longer, older fish, and growth in length declined. Recruitment declined through time ( $29 \%$ per year). If these trends continue and if immigration from nonharvested populations is limited, population density may decline by an order of magnitude within one decade. Under current conditions, resilience to harvest and environmental perturbations is probably limited.
\end{abstract}

Of the 25 extant sturgeon species, all are characterized by limited adult abundance and most are threatened (Pikitch et al. 2005). The order Acipenseriformes includes some of the most economically valuable freshwater species due to their ability to produce black caviar. The high economic value also leaves these species susceptible to the overharvest of females. Long-lived, late-maturing species are unable to compensate for intense harvest; when overharvest coincides with habitat degradation, the fishery collapses (Billard and Lecointre 2001; Ludwig et al. 2002; Secor et al. 2002). World catch of sturgeon is currently at its lowest level in recent decades (Billard and Lecointre 2001). With the recent collapse of the Caspian Sea fisheries (Birstein 1993; Billard and Lecointre 2001; Pikitch et al. 2005), fishing pressure has shifted toward North American species, such as the shovelnose sturgeon Scaphirhynchus platorynchus,

\footnotetext{
* Corresponding author: jgarvey@siu.edu
}

Received February 6, 2008; accepted November 14, 2008 Published online March 19, 2009 which is one of the few sturgeon species in the world that can be legally harvested.

Shovelnose sturgeon may be more resilient to harvest than other sturgeons because they are relatively small and, until recently, were less commercially valuable (Carlander 1954). Shovelnose sturgeon are thought to mature at the relatively early age of 5-7 years (Helms 1974; Farbee 1979), which may enable them to better withstand fishing pressure (Morrow et al. 1998). Although shovelnose sturgeon populations appear to be more stable than their European and Asian counterparts, their distribution and abundance have declined over the last century due to habitat alteration, water pollution, and overharvest (Bailey and Cross 1954; Hurley and Nickum 1984; Keenlyne 1997; Morrow et al. 1998).

Commercial fishing is currently legal in both Missouri and Illinois and occurs in the Middle Mississippi River (MMR), which extends from river kilometer (rkm) 313.8 at St. Louis, Missouri, to rkm 0 at Cairo, Illinois. In 2001, commercial harvest of shovelnose sturgeon flesh in the MMR reached a historical maximum and was increasing exponentially (Colombo et al. 2007a). No harvest data beyond 2001 are yet available from the resource agencies. However, market pressure appears to be increasing, and processed shovelnose sturgeon roe fetched US\$900 per pound as of February 2009 (based on an internet search for caviar; www.petrossian.com). By 2000, the MMR population appeared to be responding to harvest and habitat alteration with low population growth and high mortality relative to other sturgeon populations in unharvested reaches of the Mississippi River (Jackson 2004; Killgore et al. 2007). Using data collected from 2002 and 2003, Colombo et al. (2007a) found that adult abundance declined with increased harvest and year-class strength also was negatively related to harvest; both are signs of growth and recruitment overfishing (Colombo et al. 2007a).

Continual monitoring, identification of trends, and forecasting of responses are essential for sound management of fisheries. We quantified age structure of shovelnose sturgeon over a 5-year period and assessed how recruitment and sex ratio were changing through time. We also collected data from a commer- 
cial fisher to estimate sex-specific patterns and rates of harvest. Presence of a stable age structure (i.e., constant numbers of individuals in each cohort during each year) and an unchanging sex ratio despite variable environmental conditions would indicate some resiliency of the population to ongoing commercial harvest and changing environmental conditions. Conversely, changes in age structure, mortality, and sex ratio may interact with harvest and environmental variation to affect population dynamics.

\section{Methods}

The MMR extends from the mouth of the Missouri River (rkm 313.8) at St. Louis to the confluence with the Ohio River at Cairo (rkm 0). The MMR is free flowing and unimpounded but is restricted to its channel by wing dikes and revetments used to aid navigation (Pflieger 1997). These channel-training structures reduce natural fluvial processes that once created variable seasonal habitats and provided necessary in-channel and off-channel spawning and nursery habitats for many species (Sheehan and Rasmussen 1999).

During spring 2004, fork lengths (FLs; mm) and sex of shovelnose sturgeon harvested for roe or released by a single commercial fisher were quantified on three trips conducted within our sampling reach (rkm 309300; Illinois Department of Natural Resources, unpublished data). Harvest rate and the mean and median of fish caught were calculated to compare the commercial harvest data with the length-frequency data from our adult sampling.

We sampled shovelnose sturgeon during 20022006, although our sampling protocol differed through time. Standardized, stratified random sampling of shovelnose sturgeon occurred during November-April of 2002-2005; some of these data (2002-2003) are summarized by Colombo et al. (2007a). Stationary, bottom-set gill nets $(5.08-\mathrm{cm}$ bar mesh, $45 \mathrm{~m}$ long, $3 \mathrm{~m}$ deep) were placed at randomly selected sites stratified by habitat type (channel border, wing dike, island tip, and side channel) in the MMR. Given that random sampling was inefficient and size structure did not appear to differ among habitats (Garvey et al. 2006), we sampled monthly during February 2005 through June 2006 at sites where catch rates were high (hereafter, directed sampling). During each month, six nets were set for $24 \mathrm{~h}$ on the seam of wing dikes at Modoc (rkm 201-198), Chester (rkm 191-188), and Grand Tower, Illinois (rkm 127-124). Fork length and wet weight (nearest $0.1 \mathrm{~g}$ ) were quantified for each fish. During all years except 2004, the left pectoral fin ray was removed from each fish and was later used to determine fish age (Jackson et al. 2007). Pectoral fin rays were dried, and three cross sections (0.64, 0.69, and $0.74 \mathrm{~mm}$ ) were secured to a slide using cyanoacrylate. Cross sections were examined independently by two readers. A pair of opaque (growth) and translucent bands was considered an annulus (Everett et al. 2003; Jackson et al. 2007). When readers disagreed, they examined the cross sections together to reach an agreement. Annual length- and agefrequency distributions were compared across years; mean and mode were calculated for each year.

During each month in 2005-2006, the first 20 shovelnose sturgeon collected at each site were preserved on wet ice and taken back to the laboratory for anatomical determination of sex (not possible from external examination), maturation status (Colombo et al. 2007b), and weight (g wet mass). Means and medians were identified for both sexes. Mean lengths of males and females were compared among years using a one-way analysis of variance (ANOVA). A Kolmogorov-Smirnov (KS) test was used to compare length distributions between sexes. Chi-square analysis was used to determine whether the sex ratio deviated from 1:1. For all tests, the significance level was 0.10 .

Growth curves in length for the population and sexspecific growth curves during 2002, 2003, 2005, and 2006 were calculated using von Bertalanffy models in Fishery Analysis and Simulation Tools software (Slipke and Maceina 2000). Differences in sex-specific growth curves were evaluated using the residual sumof-squares method (Chen et al. 1992).

A catch curve analysis for fish at the declining portion of the log-transformed curve was used to quantify mortality rates for males and females (Ricker 1975). A weighted linear regression of log-transformed data was used to reduce any bias that may have occurred due to reduced relative abundance of older individuals in the population (Slipke and Maceina 2000). The declining slope of this regression equation represented the instantaneous mortality for the population and sex-specific mortality rates. Sex-specific catch curve slopes were tested for homogeneity (test for interaction in analysis of covariance) to determine whether mortality differed among sexes and years.

Adult shovelnose sturgeon appeared to fully recruit to our sampling gear by age 8 . We regressed $\log _{e}$ transformed relative abundance of this age-class against each year to estimate the percent decline in recruitment during 2002-2006 (i.e., from the slope of the linear regression). From this, we used our estimate of annual mortality, the relative proportion of fish in each age-class in 2006, and our estimate of declining recruitment (i.e., percent decline per year) to predict how population age structure might change in the future. In addition, we used a population estimate of 
adult shovelnose sturgeon in the MMR (160,000 fish; Garvey et al. 2006) to determine how the density of the population might change as recruitment declined, assuming no immigration.

\section{Results}

All of the 557 shovelnose sturgeon captured by the commercial fisher in 2004 were checked for eggs; $25 \%$ of these fish were harvested for eggs. Fish without black eggs were released. Mean $( \pm S D)$ size of fish harvested was $653 \pm 49 \mathrm{~mm}$ FL (median $=654 \mathrm{~mm}$ FL).

The mean FL of shovelnose sturgeon differed among years; the FL in 2002 was smaller than those in all other years, and the FL in 2004 was lower than those in 2005-2006 (ANOVA: $F=10.13$; $\mathrm{df}=4,4,306 ; P<$ 0.0001). Mean ( \pm SD) FLs were as follows: $587 \pm 69$ $\mathrm{mm}$ in $2002(n=355 ;$ median $=591 \mathrm{~mm}), 609 \pm 70$ $\mathrm{mm}$ in $2003(n=786 ;$ median $=616 \mathrm{~mm}), 602 \pm 69$ $\mathrm{mm}$ in $2004(n=1,384$; median $=614 \mathrm{~mm}), 610 \pm 64$ $\mathrm{mm}$ in $2005(n=993 ;$ median $=616 \mathrm{~mm})$, and $612 \pm$ $67 \mathrm{~mm}$ during directed sampling in 2005-2006 $(n=$ 1,384; median $=621 \mathrm{~mm}$ ). The length-frequency distributions of shovelnose sturgeon collected during 2002-2006 shifted in median and mean FL toward larger fish, and the distribution transformed from normally distributed to negatively skewed and truncated beyond $600 \mathrm{~mm}$.

During 2005 and 2006, 792 shovelnose sturgeon were subsampled to determine sex. The subsample consisted of 415 males, 363 females, and 14 fish that were either intersexual or unidentifiable. This male : female sex ratio of 1.14:1.00 deviated from $1: 1\left(\chi^{2}=\right.$ 3.48 , df $=1, P=0.06$ ). The mean ( \pm SD) FL and weight of females captured during 2005-2006 were $615 \pm 76 \mathrm{~mm}$ and $998 \pm 171 \mathrm{~g}$, respectively. Male shovelnose sturgeon had a mean FL of $609 \pm 60 \mathrm{~mm}$ and a mean mass of $936 \pm 305 \mathrm{~g}$. Length-frequency distributions differed between sexes (KS test statistic $=$ $0.06, \mathrm{df}=769, P=0.02$ ): females had a greater mean FL and a more truncated distribution than males.

Age distributions changed during 2002, 2003, 2005, and 2006. Bias (i.e., indicated by a slope different than 1.0) was not apparent in our age estimates according to an age bias plot between readers. Age-frequency distributions shifted toward older fish; mean age was 7.6 years in 2002 and 11.3 years in 2006 (Figure 1). The age-frequency distributions also changed from positively skewed to normal (Figure 1). The rightward shift in age-frequency distributions was not driven by specific cohorts growing through time (Figure 1); rather, fundamental changes in the distribution (i.e., declining number of recruits) appeared to be occurring.

Age of female shovelnose sturgeon ranged between
4 and 22 years (mean $\pm \mathrm{SD}=11.2 \pm 3.0$ years), while that of males ranged between 3 and 19 years (mean \pm $\mathrm{SD}=10.9 \pm 2.7$ years). Females became sexually mature at $9-12$ years (age at first maturation $=9$ years), and males matured at $8-10$ years (age at first maturation $=8$ years; Figure 2). At ages when females became sexually mature, the males attained larger sizes than did the females; however, after maturity was reached, females achieved larger sizes than males of the same age (Figure 2).

Population growth patterns differed among years and sexes (Table 1). The population reached a larger asymptotic length $L_{\infty}$ and the von Bertalanffy growth coefficient was greater in 2002-2003 than in 2005$2006(F=6.72, \mathrm{df}=1,27, P=0.0016$; Table 1$)$. When somatic growth was examined by age-class for each year of data, a decrease in mean FL at age occurred between 2002-2003 and 2005-2006 for all age-classes (Figure 3). The sex-specific von Bertalanffy growth curves differed ( $F=5.72 ; \mathrm{df}=1,27 ; P=0.0036)$; males reached $L_{\infty}$ at a slightly faster rate, but females attained a larger $L_{\infty}$ (Table 1 ).

Mortalities were estimated based on fish that were 7 and 9 years and older during stratified random sampling in 2002 and 2003. The instantaneous mortality rate was 0.40 in $2002\left(r^{2}=93, \mathrm{df}=8, P<\right.$ $0.0001 ; 33 \%$ annual mortality) and 0.51 in $2003\left(r^{2}=\right.$ 81 , df $=6, P=0.006 ; 40 \%$ annual mortality). For directed sampling (2005-2006), the instantaneous mortality rates were based on fish of age 12 and older because younger fish were rare in the catch. The combined instantaneous mortality rate for directed sampling (both sexes) was $0.60\left(r^{2}=96, \mathrm{df}=8, P<\right.$ $0.0001 ; 45 \%$ annual mortality). The instantaneous mortality rate during this time was 0.58 for females $\left(r^{2}=0.86, \mathrm{df}=7, P=0.0005 ; 44.3 \%\right.$ annual mortality $)$ and 0.59 for males $\left(r^{2}=0.93, \mathrm{df}=7, P<0.0001\right.$; $44.8 \%$ annual mortality). Catch curve regressions were tested for homogeneity of slopes but did not differ among sexes. Instantaneous mortality rates only differed between 2002 and the directed sampling of 2005-2006 ( $F=117$; df =3, 13; $P=0.002)$.

The relative number of fish within the age- 8 cohort declined between 2002 and $2006\left(r^{2}=0.94, \mathrm{df}=3, P\right.$ $<0.002$; slope $=29 \%$ annual decline). Assuming a starting density of 160,000 shovelnose sturgeon in 2006 , a $44 \%$ annual mortality rate, and a $29 \%$ annual decline in recruitment, we predicted that the number of fish of age 8 and older would decline to 3,200 individuals by 2016 .

\section{Discussion}

The shovelnose sturgeon population appears to be changing demographically over time in the MMR; such 


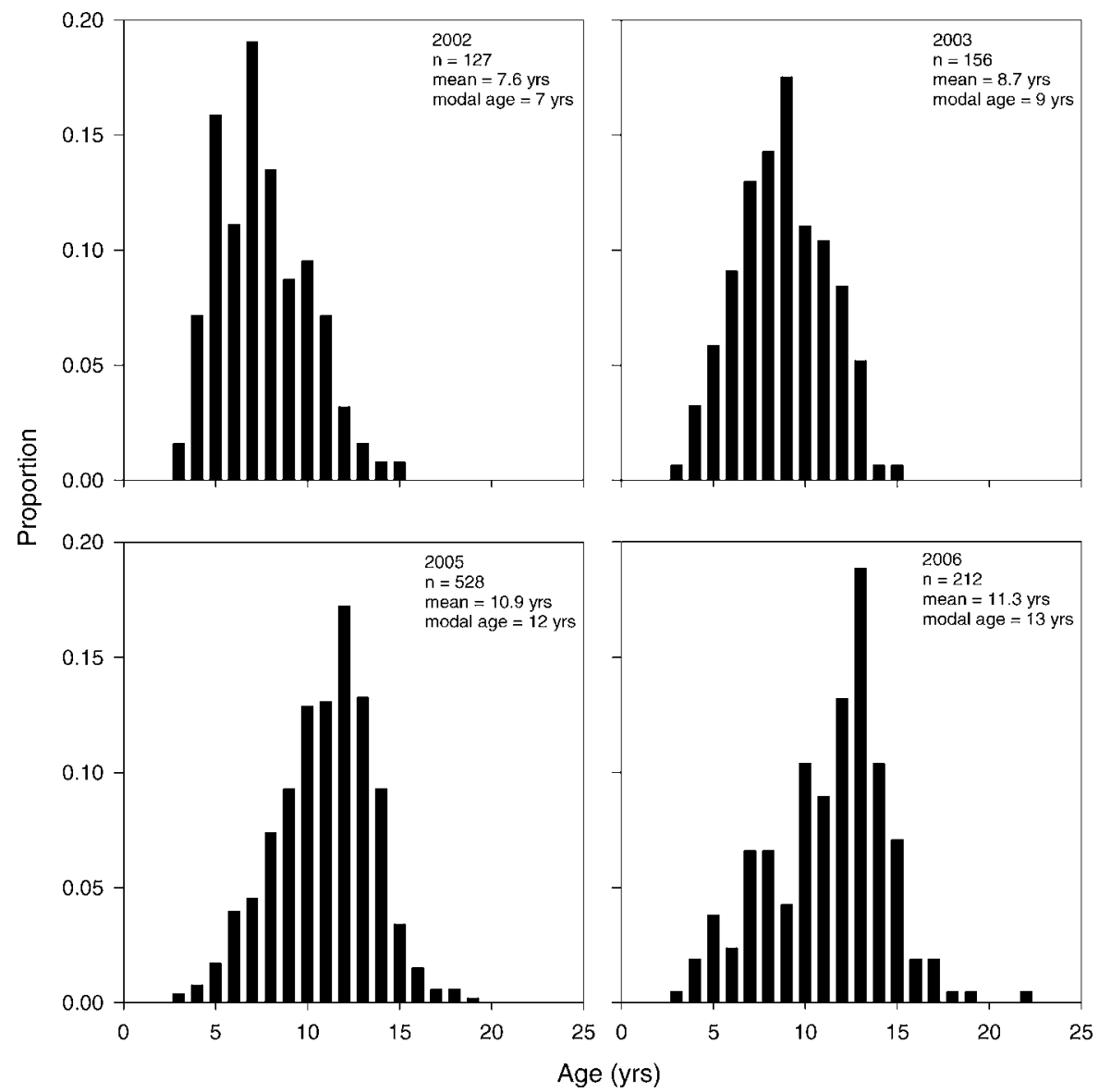

FIGURE 1.-Age-frequency distributions of the shovelnose sturgeon population in the Middle Mississippi River during 2002, 2003,2005 , and 2006 .

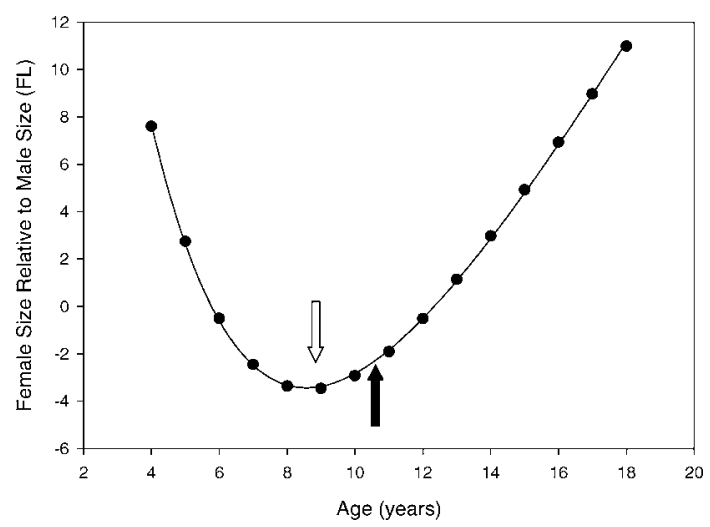

FIGURE 2.-Difference in predicted fork length (FL; mm) at each age between female and male shovelnose sturgeon in the Middle Mississippi River; predicted FLs were derived from von Bertalanffy growth curves (see Table 1). Median age at maturity for males (unshaded arrow) and females (black shaded arrow) is indicated. changes should not be occurring so rapidly in a longlived, slow-growing, late-maturing species with expected stable population structure (Winemiller and Rose 1992). Regardless of the underlying mechanisms, our very simple analysis of these monitoring data suggests that the resident population in the MMR is on a declining trajectory because mortality is increasing,

TABLE 1.-Von Bertalanffy parameters $\left(L_{\infty}=\right.$ asymptotic length, $\mathrm{mm} ; k=$ growth coefficient; $t_{0}=$ age [years] at a length of zero) estimated for the shovelnose sturgeon population sampled in the Middle Mississippi River during 2002-2003 and 2005-2006, and sex-specific parameter estimates for the 2005-2006 sample.

\begin{tabular}{clcccc}
\hline Year & Level & $L_{\infty}$ & $k$ & $t_{0}$ & $n$ \\
\hline $2002-2003$ & Population & 792.31 & 0.16 & -1.54 & 283 \\
$2005-2006$ & Population & 781.31 & 0.13 & -1.23 & 726 \\
& Male only & 770.78 & 0.14 & -1.13 & 389 \\
& Female only & 811.52 & 0.11 & -1.99 & 337 \\
\hline
\end{tabular}



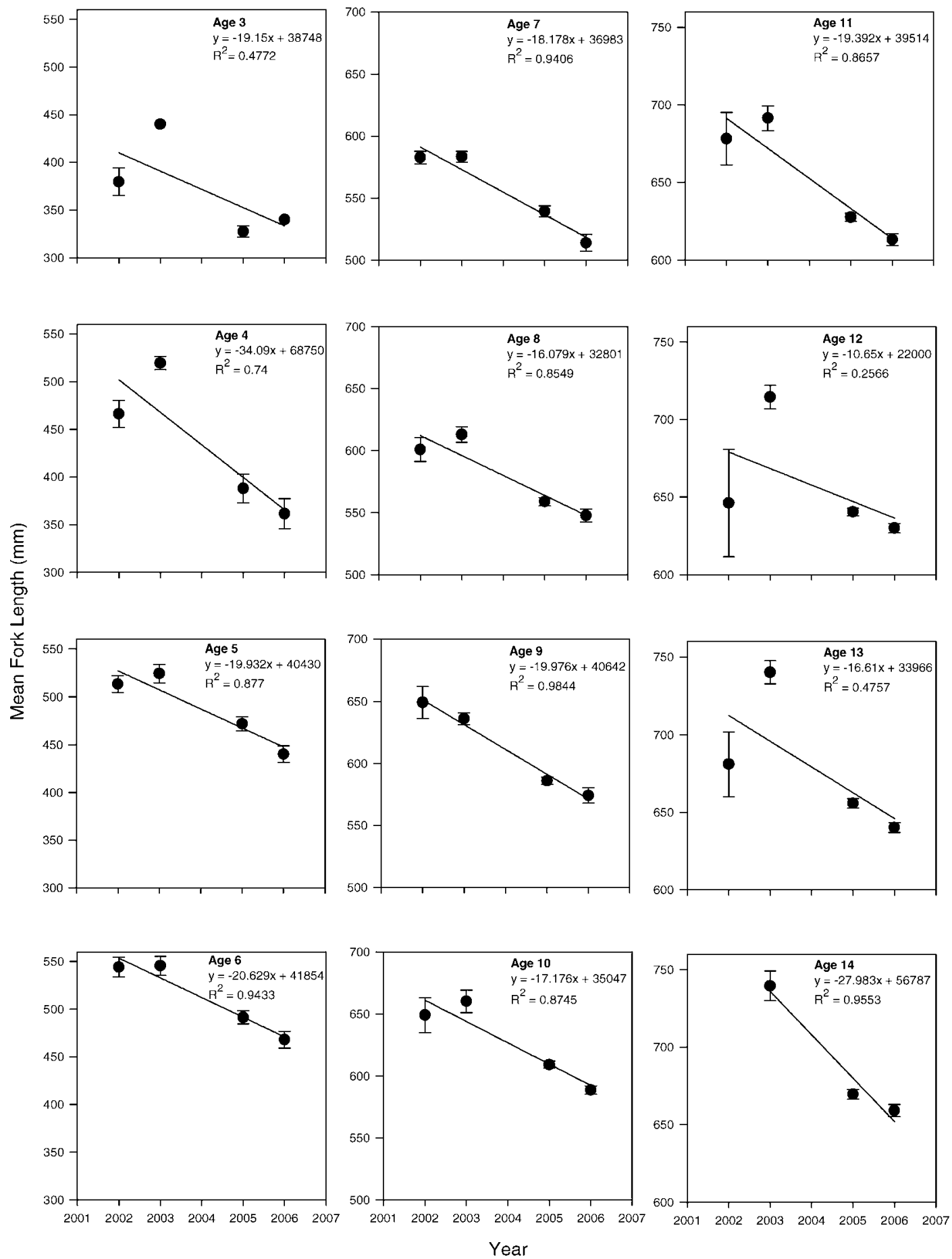

FiguRE 3.-Mean ( \pm SE) fork length (mm) of shovelnose sturgeon from each age-class in the Middle Mississippi River during 2002, 2003, 2005, and 2006. Note that the $y$-axis scale differs among panels. 
recruitment is declining, and somatic growth rates are declining. Without management intervention in the form of reduced mortality or perhaps improved habitat, this research supports previous analyses that the population will decline (Colombo et al. 2007a) and may be following the same fate as many harvested sturgeon populations (Pikitch et al. 2005). Of course, predicted declines could be ameliorated by other factors, such as immigration from other populations, a reversal of recruitment trends, and increased growth rates.

Recruitment changes that were reflected by the 8year-old cohorts through time may be due to increased harvest in the MMR that began occurring in the late 1990s, when these fish were hatched (Colombo et al. 2007a). These observed changes are characteristic of exploited fisheries experiencing a lack of spawning activity due to removal of spawning females (see Colombo et al. 2007a). To date, we know of only five potential spawning areas in the MMR, and aggregations of spawning adults are probably vulnerable in these areas (Garvey et al. 2006). Reproductive females are probably being selectively harvested on the purported spawning grounds during the October-May harvest season (Bettoli et al. 2009). Further support of the selective loss of females due to their harvest, with negative consequences for reproduction and recruitment, is reflected in the sex ratio that deviated from the 1:1 ratio observed in the MMR during 2002-2003 (Colombo et al. 2007b). We found that females became larger on average than did males after maturation; thus, females have a higher likelihood of being harvested by size-selective gear in the MMR, perhaps increasing their risk of harvest. Our estimate of $25 \%$ commercial harvest for females with black eggs further supports the assertion that harvest of females is intensive.

Although our estimate of sex ratio suggests differential mortality between females and males, our population-level analysis indicates that total annual mortality is increasing for both sexes. Harvest is probably contributing to this increase, given that the mortality rates we quantified far exceed those of unharvested shovelnose sturgeon populations ( $<10 \%$; Quist et al. 2002; Jackson 2004; Killgore et al. 2007). Males and nonreproductive females may be experiencing harvest mortality because of increased incidental effects. All fish that were collected by the commercial fisher were checked for eggs; this involves making an incision in the body wall to determine sex and maturity. This invasive procedure may increase handling mortality of both sexes in the field. The question remains whether the changing sex ratios or population-level mortality rates from catch curves are more sensitive in estimating changes in sexspecific demographics of the population.

Declining population-level growth in length through time may have been partly attributable to an unusually dry period during 2005 and 2006, which perhaps reduced foraging success or increased temperaturedependent metabolic costs. Because growth affects body size, condition, fecundity, and reproductive success, we might expect that future recruitment will be curtailed by these conditions. Habitat in the MMR is probably not ideal given the many navigation-related alterations that might produce further negative effects on recruitment success.

A major goal of fisheries science is to conserve available resources; in the case of sturgeon populations, this means that recruitment must be successful and spawning stocks must be preserved. However, if current harvest and habitat degradation persist, spawning and recruitment success will continue to decline, with negative consequences for population growth. One possible strategy to conserve the shovelnose sturgeon population is to impose conservative length limits, as suggested by Colombo et al. (2007a), to allow the population to withstand harvest. Limits on length, gear, and catch can be very effective when coupled with strict enforcement and close monitoring (Williamson 2003), but such regulations are difficult to enforce, particularly on such a large system, and may not be the best option. Although specific spawning areas have not been located in the MMR, aggregations occur at specific locations during the spawning season. If such areas could be protected at the appropriate times, spawning by a majority of the mature females is possible. Enhancement and perhaps an increase in these spawning areas may relax the purported recruitment bottleneck. A temporary ban on harvest may also be successful as it has been for other sturgeon populations (Pikitch et al. 2005), but the signs of recovery may not be seen for many years. The best management plan for shovelnose sturgeon population recovery will probably be a combination of regulations and restrictive harvest with strict enforcement and monitoring. On a longer time scale, identifying whether successful spawning is limited by habitat and responds positively to habitat restoration will be important for allowing populations to resist harvest and environmental perturbations.

\section{Acknowledgments}

We thank the Illinois Department of Natural Resources for collecting and supplying the commercial harvest data. Special thanks to Mike Hill for assistance in field collection and aging of all shovelnose sturgeon and to Quinton Phelps for assistance in manuscript preparation; we are also grateful to P. Beck, R. Echols, D. Knuth, A. Lohmeyer, A. Plauck, and D. Schultz for assistance with field collection. Funding for this 
research was provided by the U.S. Army Corps of Engineers St. Louis District. Thomas Keevin was particularly helpful during this process.

\section{References}

Bailey, R. M., and F. B. Cross. 1954. River sturgeons of the American genus Scaphirhynchus: characters, distribution, and synonymy. Papers of the Michigan Academy of Science, Arts, and Letters 39:169-208.

Bettoli, P. W., M. Castro-Yerty, G. D. Scholten, and E. J. Heist. 2009. Bycatch of the endangered pallid sturgeon (Scaphirhynchus albus) in a commercial fishery for shovelnose sturgeon ( $S$. platorynchus). Journal of Applied Ichthyology 25:1-4.

Billard, R., and G. Lecointre. 2001. Biology and conservation of sturgeon and paddlefish. Reviews in Fish Biology and Fisheries 10:355-392.

Birstein, V. J. 1993. Sturgeons and paddlefish: threatened fishes in need of conservation. Conservation Biology 7:773-787.

Carlander, H. B. 1954. History of fish and fishing in the upper Mississippi River. Upper Mississippi River Conservation Commission, Rock Island, Illinois.

Chen, Y., D. A. Jackson, and H. H. Harvey. 1992. A comparison of von Bertalanffy and polynomial functions in modeling fish growth data. Canadian Journal of Fisheries and Aquatic Sciences 49:1228-1235.

Colombo, R. E., J. E. Garvey, N. D. Jackson, B. T. Koch, R. Brooks, D. P. Herzog, R. A. Hrabik, and T. W. Spier. 2007a. Harvest of Mississippi River sturgeon drives abundance and reproductive success: a harbinger of collapse? Journal of Applied Ichthyology 23:444 451.

Colombo, R. E., J. E. Garvey, and P. S. Wills. 2007b. Gonadal development and sex-specific demographics of the shovelnose sturgeon (Scaphirhynchus platorynchus) in the Middle Mississippi River. Journal of Applied Ichthyology 23:420-427.

Everett, S. R., D. L. Scarnecchia, G. J. Power, and C. J. Williams. 2003. Comparison of age and growth of shovelnose sturgeon in the Missouri and Yellowstone rivers. North American Journal of Fisheries Management 23:230-240.

Farbee, G. B. 1979. Life histories of important sport and commercial fishes of the upper Mississippi River, shovelnose sturgeon. Pages 41-68 in Jerry L. Rasussen, editor. A compendium of fishery information on the upper Mississippi River, 2nd edition. Upper Mississippi River Conservation Committee, Rock Island, Illinois.

Garvey, J. E., E. J. Heist, R. C. Brooks, D. P. Herzog, R. A. Hrabik, and K. J. Killgore. 2006. Current status of the pallid sturgeon (Scaphirhynchus albus) in the Middle Mississippi River: habitat, movement, and demographics. Final Report to U.S. Army Corps of Engineers St. Louis District, St. Louis, Missouri.

Helms, D. R. 1974. Shovelnose sturgeon in the Mississippi River, Iowa. Iowa Fisheries Research Technical Series 74-3. Iowa Conservation Commission, Des Moines.

Hurley, S. T., and J. G. Nickum. 1984. Spawning and early life history of shovelnose sturgeon. Iowa Cooperative Fish and Wildlife Research Unit, Iowa State University,
Project Segment 2-399-R-1, Completion Report. Iowa State University, Ames.

Jackson, N. D. 2004. Age, growth, and mortality of shovelnose sturgeon, Scaphirhynchus platorynchus, in the Middle Mississippi River and lower Wabash River, Illinois. Master's thesis. University of Southern Illinois, Carbondale.

Jackson, N. D., J. E. Garvey, and R. E. Colombo. 2007. Comparing aging precision of calcified structures in shovelnose sturgeon. Journal of Applied Ichthyology 23:525-528.

Keenlyne, K. D. 1997. Life history and status of the shovelnose sturgeon, Scaphirhynchus platorynchus. Environmental Biology of Fishes 48:291-298.

Killgore, K. J., J. J. Hoover, J. P. Kirk, S. G. George, B. R. Lewis, and C. E. Murphy. 2007. Age and growth of pallid sturgeon in the free-flowing Mississippi River. Journal of Applied Ichthyology 23:452-456.

Ludwig, A., L. Dubus, and I. Jenneckens. 2002. A molecular approach to control the international trade in black caviar. International Review of Hydrobiology 87:661674.

Morrow, J. V., J. P. Kirk, K. J. Killgore, and S. G. George. 1998. Age, growth, and mortality of shovelnose sturgeon in the lower Mississippi River. North American Journal of Fisheries Management 18:725-730.

Pflieger, W. L. 1997. The fishes of Missouri, 2nd edition. Missouri Department of Conservation, Jefferson City.

Pikitch, E. K., P. Doukakis, L. Lauck, P. Charkrabarty, and D. L. Erickson. 2005. Status, trends and management of sturgeon and paddlefish fisheries. Fish and Fisheries 6:233-265.

Quist, M. C., C. S. Guy, M. A. Pegg, P. J. Braaten, C. L. Pierce, and V. H. Travnichek. 2002. Potential influence of harvest on shovelnose sturgeon in the Missouri River System. North American Journal of Fisheries Management 22:537-549.

Ricker, W. E. 1975. Computation and interpretation of biological statistics of fish populations. Bulletin of the Fisheries Research Board of Canada 191.

Secor, D. H., P. J. Anders, W. Van Winkle, and D. A. Dixon. 2002. Can we study sturgeon to extinction? What we know and don't know about the conservation of North American sturgeon. Pages 183-189 in W. Van Winkle, P. J. Anders, D. H. Secor, and D. A. Dixon, editors. Biology, management, and protection of North American sturgeon. American Fisheries Society, Bethesda, Maryland.

Sheehan, R. J., and J. L. Rasmussen. 1999. Large rivers. Pages 529-559 in C. C. Kohler and W. A. Hubert, editors. Inland fisheries management in North America, 2nd edition. American Fisheries Society, Bethesda, Maryland.

Slipke, J. W., and M. J. Maceina. 2000. Fisheries Analysis and Simulation Tools (FAST) user's guide. Auburn University, Auburn, Alabama.

Williamson, D. F. 2003. Caviar and conservation: status, management, and trade of North American sturgeon and paddlefish. TRAFFIC North America, Washington, D.C.

Winemiller, K. O., and K. A. Rose. 1992. Patterns of lifehistory diversification in North American fishes: implications for population regulation. Canadian Journal of Fisheries and Aquatic Sciences 49:2196-2218. 